\title{
Design and Development of Surgical Gown using Red Seaweed Extract for Hygienic Textiles
}

\author{
JanarthananM $^{1}$ | GobalakrishnanM ${ }^{1}$ | Senthil KumarM²
}

${ }^{1}$ Assistant Professor, Textile Technology, Bannari Amman Institute of Technology, Sathyamangalam, Erode, Tamil Nadu, India.

${ }^{2}$ Associate Professor, Textile Technology, PSG college of Technology, Coimbatore,Tamil Nadu, India.

\section{To Cite this Article}

JanarthananM, GobalakrishnanM and Senthil KumarM, "Design and Development of Surgical Gown using Red Seaweed Extract for Hygienic Textiles", International Journal for Modern Trends in Science and Technology, 6(9S): 45-53, 2020.

\section{Article Info}

Received on 25-August-2020, Revised on 08-September-2020, Accepted on 12-September-2020, Published on 18-September-2020.

\section{ABSTRACT}

The drastic growth in the area of technical textiles and their end-use in healthcare and hygienic textiles create numerous opportunities for the application of novel finishing agents. Novel finishing agents with improved functionality act as natural antimicrobial agents will help to reduce the adverse effects caused by microbes and it is used for several end applications particularly in the barrier material and infection control. The present study was to develop the surgical gown and investigate the presence of bioactive compounds present in the Acanthophora Spicifera seaweed and analysis the antioxidant and antimicrobial activity of the extract and the treated fabrics using DPPH scavenging activity, disc diffusion, and ENISO20645 test methods. The extractobtained from red seaweed is applied to the bamboo fabric using the pad-dry-cure method for making surgical gown material. The test result shows that the maximum antibacterial activity of the $28 \mathrm{~mm}$ inhibition zone was observed and the maximum antioxidant inhibition percentage of $77 \pm 0.17 \%$ for both extract and treated fabrics. The presence of bioactive compounds such as flavonoids, tannins, phenols, saponins, and Anthocyanins in the herbal extract was analyzed by using Thin Layer Chromatography (TLC) and the functional group present in the herbal extract was analyzed by Fourier Transform Infrared Radiation Spectroscopy (FTIR). The physical and comfort properties like air permeability, tensile strength, tearing strength, and wicking behaviour of the treated fabrics were decreases compared to untreated fabrics. Thetreated fabrics are used for a variety of medical applications such as gloves, surgical drapes, wound healing,operation room table covers, and face masks for hygienic and healthcare textiles.

KEYWORDS:Red seaweed, Antioxidant activity, Antibacterial activity, Bioactive compounds, Comfort properties.

\section{INTRODUCTION}

Medical textiles have a numerous opportunities for many textile manufacturers, and the textile materials made of knitted, woven, non-woven and composite have been used for the different health care and medical applications [1]. Medical applications can be categorized in to implantable and non-implantable applications. Implantable materials such as surgical suture, artificial skin, artificial ligament, and artificial cartilage. Non-implantable materials such as gauze, pressure bandages, surgical gowns, surgical masks, bed covers, upholstery fabrics, nappies, and face masks have to attain the highest standard properties [2]. Hygienic textiles help to prevent infection control and preserve health for human 
life. Inorder to facilitate hygienic products made of textile materials can be used for personal life and healthcare properties.An numerous growth in medical textiles helps to get better comfort nature for patients and end-users [3]. Most of the hygiene products are disposable in nature due to environment friendly and the important prerequisites for successful healthcare products are durable, non-toxicity, mechanical properties, elasticity, non-allergic and biocompatibility. Nowadays, most of the textile products fall in the medical and health care sector is disposable and remaining textile products can be reused after suitablesterilization/cleaning.

Nonwovens are most widely used in the field of non-implantable devices and hygiene products. The development of updating technology and novelty fibres helps to produce compatible, cheaper, pioneering and biodegradable products. Most predominantly used fibres such as cotton, polypropylene, polysaccharides, viscose, polyester, hollow fibre, and elastomeric fibres are used inmedical textiles[4].

Seaweed is a marine plant that is found in every sea or ocean and may belong to one of several groups of multicellular algae. Seaweeds consist of three different groups based on thallus colours such as red, green, and brown seaweeds. Marine macroalgae have a brilliant source of bioactive compounds with various functional activities such as antifungal, anticoagulant, antiviral, antitumor, antibacterial, and anti-inflammatory properties. Seaweeds are used as medicine in older daysand eaten by people in coastal areas. Trace minerals found in seaweeds are regularly used as herbal medicine to conquer inflammation and curing of various infectious diseases like allergy, cancer, influenza, common cold, and tuberculosis. The extracts derivedfrom the seaweedscan be used as a good nutrient for food supplements and act as an anti-inflammatory agent to cure immunologic disorders and allergic diseases in the pharmaceutical industry[5].

Red algae have various bioactive compounds such as phenols, terpenoids, ketones, alkanes, amino acids, phlorotannins, acrylic acid, and saponins [6,7]. The Acanthophora Spicifera species have excellent anti-microbial, anti-oxidant, anti-fouling, ultraviolet-screening agents, anti-tumor and anti-allergy properties compared to other seaweeds. All seaweeds have a phenolic compound in its functional group can act as an excellent antioxidant and antimicrobial activities. Largest phenolic compounds in seaweeds constitute flavonoids that identify the wide band of biological activities including anti-oxidant, anti-viral, and anti-fouling properties[8]. Steroids, terpenoids, and saponins present in the red seaweed have higher antioxidant activities and also the secondary metabolites present in all seaweeds have a higher potential for pharmaceutical application[9].In this study, the extract obtained from red seaweed applied to the bamboo fabric used for making a surgical gown for hygienic textiles.

\section{MATERIALS AND METHODS}

The sample of Acanthophora Spicifera of edible red seaweed hasa good amount of nutrients, anti-oxidant, and antibacterial activities. They were freshly collected from thonidurai coast of mandapam and were rinsed in seawater and packed in aseptic bags and brought to the laboratory for further processing. The bamboo fabric(4 meters) was purchased fromSri Karthikeyan Textiles, Karur. The fabric parameters are listed as shown in Table 2.1.The chemicals such as Methanol, pectinase and cellulase enzyme, sodium phosphate buffer solution, citric acid,2, 2-Diphenyl-1- picrylhydrazyl, chloramphenicol, ascorbic acidand nutrient agar of laboratorygrade have purchased from the Sri Mahalakshmi Scientific Company, Coimbatore.

TABLE 2.1 FABRICPARAMETERS

\begin{tabular}{|c|l|c|}
\hline $\begin{array}{c}\text { S.No } \\
.\end{array}$ & \multicolumn{1}{|c|}{ Parameters } & $\begin{array}{c}\text { Bamboo } \\
\text { Fabric }\end{array}$ \\
\hline 1. & Structure & Plain \\
\hline 2. & Picks per Inch & 88 \\
\hline 3. & Ends Per Inch & 100 \\
\hline 4. & Yarn Count & $40 \mathrm{Ne}$ \\
\hline 5. & GSM & 140 \\
\hline
\end{tabular}

\section{Extraction of Red Seaweed}

A $30 \mathrm{~g}$ of powdered seaweed sample was filtered in a Whatman No. 1 filter paper thimble was placed into an extraction chamber. The extraction chamber was then connected to a flask containing $300 \mathrm{ml}$ of methanol with a ratio of 1:5 (Seaweed: Methanol), then stirred with a magnetic mixer for 3 hours, and the extraction was filtered using Whatman No.1 filter paper. The constant heat source was supplied for this procedure $\left(50^{\circ} \mathrm{C}\right)$ for 24 hours until the extract was clear. All the extracts were concentrated under reduced pressure using a rotary evaporator at a temperature of $60^{\circ} \mathrm{C}$. The final concentrate after extraction was dissolved in methanol and stored at $4^{\circ} \mathrm{C}$ for further process as shown in Fig. 2.1[10]. 


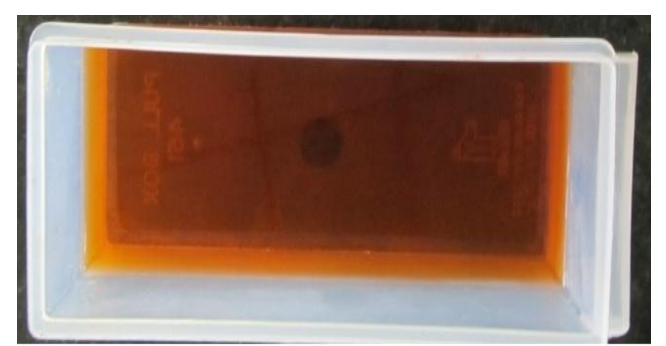

\section{Fig 2.1: Herbal extract of Acanthophora Spicifera(Red seaweed)}

\section{Enzyme Scouring}

The fabric was immersed in the pectinase solution with $0.05 \mathrm{M}$ sodium phosphate buffer at $55^{\circ} \mathrm{C}, \mathrm{M}: \mathrm{L}$ ratio of $1: 50$ for 1 hour. After treatment, the temperature was raised to $100^{\circ} \mathrm{C}$ for $10 \mathrm{~min}$ to stop the enzyme activity. The fabric was washed with hot water followed by cold water and dried[11].

\section{Enzyme Bleaching}

The scoured bamboo fabric was taken and placed in a $0.1 \mathrm{M}$ sodium phosphate buffer solution $(\mathrm{pH}$ 7.0). Add cellulase to it and mix well and incubate at $50^{\circ} \mathrm{C}$ for 3 hours. Inactivate the enzyme by boiling water for $5 \mathrm{~min}$. The fabric was washed thoroughly in tap water and then in distilled water, dried in air for 1hour[12].

\section{Finishing Process Wet Dip Method}

The method of dipping is done by immersing the fabric material in the treatment bath containing the Acanthophora Spicifera extract for 5 minutes. The fabric was removed from the bath and squeezed gently and dried in air. The fabric is finished using a wet dip method as a continuous process. The extract made from Acanthophora Spicifera is applied to the fabric for finishing and citric acid is used as a binder for fixation of the extract to the bamboo fabric. The fabric is dried for 30 minutes at $60^{\circ} \mathrm{C}[13]$.

\section{Assessment of bioactive compoundsusing Thin Layer Chromatography(TLC)}

The TLC technique was used to separate non-volatile mixtures. The investigationwas conducted using a sheet of aluminum foil coated with a thin layer of silica gel. The activate TLC plates were applied toAcanthophora Spicifera extract with the help of capillary tube at a $1 / 2$ inch apart from the lower edge of TLC plate, and the TLC plate was kept in a developing chamber containing suitable solvent system for a specific time until the developing solvent reaches the top of the upper edge of TLC plate. The TLC plate was taken out of the developing chamber, dried and the solvent front is marked by lead pencil [14]. The compounds have a higher affinitythat will move slowly towards the stationary phase and the compounds with lower affinitywill travel fast. In the separation process, the bioactive compounds present in the extract appear as spots at respective levels on the TLC chromatoplate by using suitable spraying reagent for the presence of specific compounds. The visualized spots of the components in the chromatoplate are marked and the $\mathrm{R} f$ value of each spot is calculated by the formula:

$\mathrm{R}_{f}=$ Distance travelled by sample $(\mathrm{cm})(1)$

$$
\text { Distance travelled by solvent }(\mathrm{cm})
$$

Investigate the functional group of red seaweed extract using Fourier Transform Infrared Radiation Spectroscopy (FTIR)

The functional groups present in the red seaweed extract shows the presence of bioactive compounds isrecognized using FTIR spectroscopy. A peak value arisesin the form of spectral curves at various wavelengths with the help of infrared radiation was measured. FTIR absorption spectra can be varied according to the extract solution and the spectral curve formed with respect to different wavelengths from $400-4000 \mathrm{~cm}^{-1}$ was recorded using a Thermo ScientificNicolet iS10 FTIR Spectrometer, USA. Take $3 g$ of powdered seaweed extract added with $18 \mathrm{~g}$ of potassium bromide was filled using mortar with the ratio of $1: 6$. The large crystal present in the mixtures is broken down in to smaller ones using pestle are grinded thoroughly. Then place the mixture in the pellet diesefficiently and pressure is applied to form pellets. The pellet is placed in the FTIR sample pellet holder. The changesin the functional group existing in the red seaweed extract were revealed during this analysis [15].

\section{Assessment of the AntioxidantActivityDPPH} radical scavenging activity

Free radical scavenging activity was measured by 2,2-Diphenyl-1-picryl hydrazyl (DPPH) according to the method of Yen and Chen (1995)[16]. Briefly, a $4.0 \mathrm{ml}$ aliquot of the test sample was added to $4.0 \mathrm{ml}$ of $0.16 \mathrm{ml} \mathrm{DPPH}$ solution. The mixture was shaken vigorously, then left to stand at room temperature for $30 \mathrm{~min}$ in darkness. Changes in the absorbance of the samples were measured at 517 NM using a UV spectrophotometer. The ability 
to scavenge the DPPH radical was evaluated using the following equation:

Scavenging effect (\%)

$=1-\left(\right.$ Asample $^{-}$A $\left._{\text {Sampleblank }}\right)(2)$

A control

Where:

$\mathrm{A}_{\text {control }}$ is the absorbance of the control (DPPH solution without sample),

$\mathrm{A}_{\text {sample }}$ is the absorbance of the test sample (DPPH solution plus test sample),

A sample blank is the absorbance of the sample only (sample without any DPPH solution).

Ascorbic acid was used as a positive control.

\section{Assessment of Antibacterial Activity Disc diffusion method for extract}

The antibacterial activity of the extract was evaluated using disc diffusion method. Briefly, $6 \mathrm{~mm}$ paper disks were impregnated with two different concentrations $100 \mu$ land $200 \mu 1$ using methanol of seaweed extract and left dried on the disc. Then the discs were applied to the agar plates that were inoculated previously with the test organisms (Staphylococcus Aureus and Escherichia Coli) and incubated for 1 hour. The bacterial plates were incubated at $35^{\circ} \mathrm{C}$ for 28 hours. The chloramphenicol was used as a positive control for twodifferent concentrations (100 and $200 \mu \mathrm{g} / \mathrm{disc}$ ). After incubation, all plates were observed inthe zone of inhibition and the diameter of the zones was measured in millimeter. All tests were carried out three times under sterile conditions[17].

ENISO 20645 anti-bacterial method for treated fabrics

The nutrient agar plates were prepared by pouring $15 \mathrm{ml}$ of agar media into sterile petri plates. The plates were allowed to solidify for $5 \mathrm{~min}$ and the test bacterial culture (Staphylococcus aureus and Escherichia coli) was inoculated uniformly and dry for 10 minutes. The control and treated fabric were cut into $2.5-3 \mathrm{~cm}$ size and placed over the inoculated test bacterial cultures, separately. The plates were kept inincubation at $39^{\circ} \mathrm{C}$ for 24 hours. After incubation, the inhibition zone present around the fabric was calculated in millimeters and recorded[18].

\section{Evaluation of fabric properties}

The physical and comfort properties of fabric were carried outusing the ASTM standards, and AATCC test methods. The standard atmospheric condition was maintained with a temperature of $27^{\circ} \mathrm{C}$, and $65 \pm 2 \% \mathrm{RH}$. The fabric tensile strength was evaluated according to standard ASTM D5034-95.
The fabric tearing strength was measured according to standardASTM D1424-96. The quantity of air passes per second through one square $\mathrm{cm}$ of the fabric was calculated according to standard ASTM D737-04. The degree of colour change and colour staining was evaluated according to standard AATCC61-13. The extraction has a pale red colour and the quantity of colour removed from the treated fabric both in wet and dry conditions was calculated according to standard AATCC TM08-96. The vertical wicking behaviour of the fabrics was evaluated according to standard AATCC 197-11[26].

\section{Development of Woven Surgical Gown}

The surgical gown is made on the treated bamboo fabric.The pattern is made according to the standard specificationsgiven for surgical gown. The treated fabric was cut according to the pattern and stitch the cut fabric as the surgical gownis shown in Fig. 2.2.

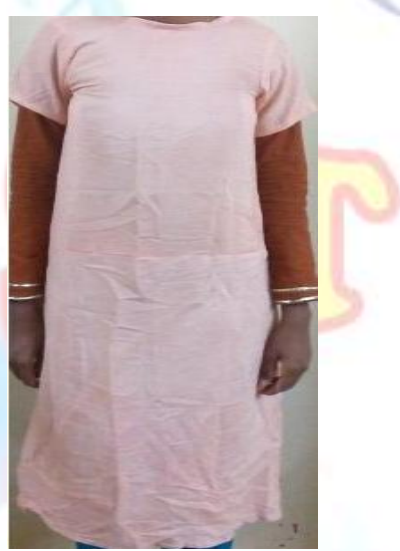

Fig 2.2: Developed Surgical Gown

A low density seam is given for the gown to attain lower bulkiness. The yoke part is provided in front of the surgical gown.Ropes are made on the back pattern for making the knot in the surgical gown.Comfortably, the surgical gown was developed for hygienic applications.

\section{RESULT AND DISCUSSIONS}

Assessment of bioactive compounds in Acanthophora Spicifera extractusing TLC technique

The dissolving solvent act as a mobile phase with the help of a suitable spraying agent was used to identify the bioactive compounds present in the Acanthophora Spicifera extract are presented in Table 3.1. The precise spot colour and its $R_{\mathrm{f}}$ values produced in seaweed extract are shown in Fig.3.1 and 3.2[19]. 


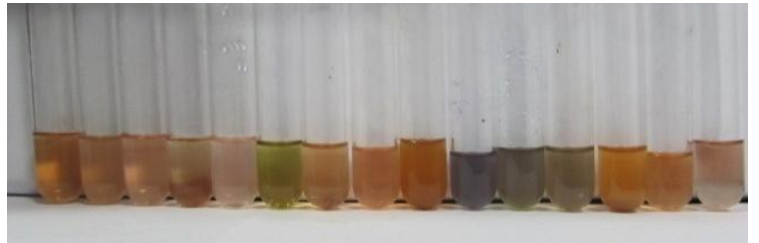

Fig 3.1: Analysis of bioactive compounds in Acanthophora Spicifera extract

Table 3.1 Assessment of bioactive compounds using TLC Technique

\begin{tabular}{|c|c|c|c|c|}
\hline $\begin{array}{c}\text { Bioactive } \\
\text { compounds }\end{array}$ & $\begin{array}{c}\text { Mobile } \\
\text { phase }\end{array}$ & $\begin{array}{c}\text { Spraying } \\
\text { reagent }\end{array}$ & $\begin{array}{c}\text { Spot } \\
\text { colour }\end{array}$ & $\begin{array}{c}\text { Rf } \\
\text { Valu } \\
\text { em }\end{array}$ \\
\hline Flavonoids & $\begin{array}{c}\text { Ethyl } \\
\text { acetate: } \\
\text { Butanol: } \\
\text { Formic acid } \\
(2: 2: 1)\end{array}$ & $\begin{array}{c}\text { Aluminiu } \\
\text { m chloride }\end{array}$ & Orange & 0.92 \\
\hline Phenols & $\begin{array}{c}\text { Chloroform: } \\
\text { Methanol } \\
(25: 1)\end{array}$ & $\begin{array}{c}\text { Ferric } \\
\text { chloride } \\
\text { reagent }\end{array}$ & Blue & 0.89 \\
\hline Tannin & $\begin{array}{c}\text { Methanol: } \\
\text { Water (6:4) }\end{array}$ & $\begin{array}{c}\text { Ferric } \\
\text { chloride } \\
\text { reagent }\end{array}$ & $\begin{array}{c}\text { Browni } \\
\text { sh grey }\end{array}$ & 0.86 \\
\hline Saponins & $\begin{array}{c}\text { Methanol: } \\
\text { Water (7:3) }\end{array}$ & $\begin{array}{c}\text { Ferric } \\
\text { chloride }\end{array}$ & $\begin{array}{c}\text { Light } \\
\text { Orange }\end{array}$ & 0.62 \\
\hline Anthocyanin & $\begin{array}{c}\text { Acetonitrile: } \\
\text { Water: } \\
\text { Formic acid } \\
(2: 2: 1)\end{array}$ & Acetic \\
acid & $\begin{array}{c}\text { Pink } \\
\text { colour }\end{array}$ & 0.30 \\
\hline
\end{tabular}
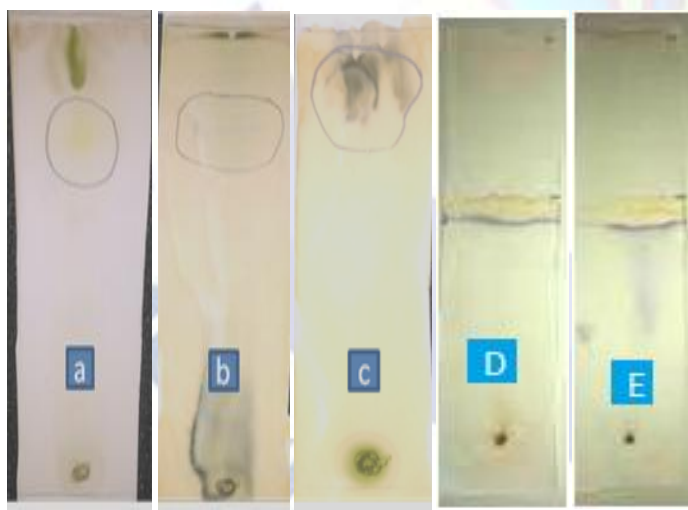

Fig 3.2: Presence of (a) Flavonoids (b) Phenols (c) Tannins (d) Saponins (e) Anthocyanins in Acanthophora Spicifera extract

The figure 3.1 and 3.2 shows that the Acanthophora Spiciferaextract has the presence of five major bioactive compounds such as flavonoids, phenol, saponins, anthocyanins and tannin attributing for their anti-bacterial,antiviral, antitumor, anti-cancer and anti-inflammatory properties[19].
Assessment of functional groups in Acanthophora Spicifera extract using FTIR Spectroscopy

FTIR spectrum was used to identify the functional groups present in the seaweed extract based on the peak value in the region of the infrared spectrum as shown in Fig. 3.3. The prominent peaks occur in $3354.65 \mathrm{~cm}^{-1}, \quad 2919.59 \mathrm{~cm}^{-1}, 2364.78 \mathrm{~cm}^{-1}$, and $2135.57 \mathrm{~cm}^{-1}$ represents the major functional groups such as phenols, amines, alkane and aldehydes present in the seaweed extract[20].The prominent peaks occur at $1757.48 \mathrm{~cm}^{-1}$, $1639.74 \mathrm{~cm}^{-1}$, and $1417.60 \mathrm{~cm}^{-1}$ represents the major functional groups such as carboxylic acid and alkene present in the seaweed extract. The prominent peaks occur in $1155.89 \mathrm{~cm}^{-1}, 1000 \mathrm{~cm}^{-1}$, and895.64 $\mathrm{cm}^{-1}$ represents the major functional groups such as ketone, anhydride and alkene present in the seaweed extract as shown in Table 3.2 .

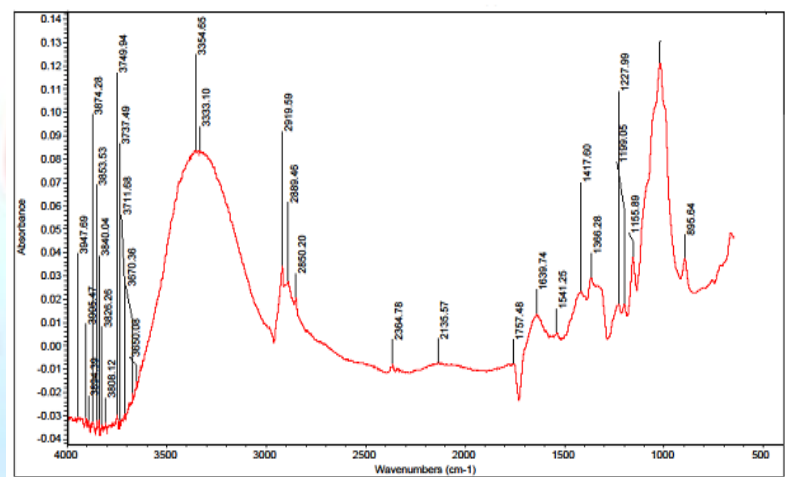

Fig 3.3:FTIR Spectroscopy for Acanthophora Spiciferaextract

Table 3.2FTIR analysis for Acanthophora Spiciferaextract with respect to wavelength

\begin{tabular}{|c|c|c|c|c|}
\hline $\begin{array}{c}\text { S. } \\
\text { No. }\end{array}$ & $\begin{array}{c}\text { Wavelength } \\
\text { (cm - } \mathbf{~}\end{array}$ & $\begin{array}{c}\text { Bond / } \\
\text { Stretching }\end{array}$ & Intensity & $\begin{array}{c}\text { Functional } \\
\text { Group }\end{array}$ \\
\hline 1. & 3354.65 & N-H Stretch & Medium & $\begin{array}{c}\text { Phenols and } \\
\text { Amines }\end{array}$ \\
\hline 2. & 2919.59 & $\begin{array}{c}\text { C-H } \\
\text { stretching }\end{array}$ & Medium & Alkane \\
\hline 3. & $\begin{array}{c}2364.78 \& \\
2135.57\end{array}$ & $\begin{array}{c}\text { C-H stretch } \\
\text { C=O } \\
\text { stretching }\end{array}$ & Medium & Aldehyde \\
\hline 4. & 1757.48 & $\begin{array}{c}\text { Carboxylic } \\
\text { acid }\end{array}$ \\
\hline 5. & 1639.74 & C stretch & Weak & Alkene \\
\hline 6. & 1417.60 & $\begin{array}{c}\text { O-H } \\
\text { bending }\end{array}$ & Strong & $\begin{array}{c}\text { Carboxylic } \\
\text { acid }\end{array}$ \\
\hline 7. & 1155.89 & $\begin{array}{c}\text { C=O } \\
\text { CO-O-CO } \\
\text { stretching }\end{array}$ & $\begin{array}{c}\text { Very } \\
\text { strong }\end{array}$ & Anhydride \\
\hline 8. & 1000 & $\begin{array}{c}\text { C=C } \\
\text { bending }\end{array}$ & Strong & Alkene \\
\hline 9. & 895.64 & $\begin{array}{c}\text { C=C } \\
\text { bending }\end{array}$ & Strong & Alkene \\
\hline 10. & 694 & & \\
\hline
\end{tabular}


The peak present in the spectrum has confirmed the presence of functional groups such as flavonoids, anthocyanins, phenols, tannin, and saponins compounds present in the treated fabric. The functional groups present in the seaweed extract are responsible for antibacterial, antiviral, antitumor, anti-cancer, and anti-inflammatory properties.

\section{Evaluation of Antioxidant Activity}

The antioxidant activity of Acanthophora Spicifera was measured using the DPPH method. The result shows that the antioxidant activity increases with increasing the concentration of the extract and treated fabric sample[21].

\section{Seaweed Extract}

The antioxidant property of Acanthophora Spicifera extract was analyzed by the DPPH radical scavenging method. The percentage of scavenging activity present in the red seaweed extract is shown in Table 3.3.

Table 3.3 Antioxidantactivity of the methanol extract

\begin{tabular}{|c|c|c|c|}
\hline S.No. & $\begin{array}{c}\text { Seaweeds } \\
\text { Name }\end{array}$ & $\begin{array}{c}\text { DPPH Free Radical Scavenging } \\
\text { Activity \% Inhibition }\end{array}$ \\
\cline { 3 - 4 } & $\begin{array}{c}\text { Ascorbic Acid } \\
\text { Aqueous Extract }\end{array}$ \\
\hline 1. & $\begin{array}{c}\text { anthophora } \\
\text { Spicifera }\end{array}$ & $77 \pm 0.17$ & $24.85 \pm 2.87$ \\
\hline
\end{tabular}

The results indicate that the percentage of radical scavenging activity increases, with an increase the concentration of ascorbic acid and aqueous extract. The antioxidant property of the seaweed extract will help to reduce the number of free radicals present in the oxygen species and fast growth of cell membrane present in the skin.

\section{Treated Fabric}

The percentage of free radical scavenging activity of treated fabric was analyzed by the DPPH method. The test results are shown in Table 3.4.

\section{Table 3.4 Antioxidant activity of the treated}

fabric

\begin{tabular}{|c|c|c|c|}
\hline \multirow{2}{*}{ S.No. } & \multirow{2}{*}{ Treated fabric } & $\begin{array}{r}\text { DPPH Free Radical Scavenging } \\
\text { Activity \% Inhibition }\end{array}$ \\
\cline { 3 - 4 } & Ascorbic acid & Aqueous Extract \\
\hline 1. & $\begin{array}{c}\text { Acanthophora } \\
\text { Spicifera }\end{array}$ & $76 \pm 0.26$ & $23.95 \pm 1.12$ \\
\hline
\end{tabular}

The test result of the treated fabric shows that the percentage of radical scavenging activity was more or less the same for seaweed extract and treated fabric. The antioxidant activity helps to trap the free radial oxygen species and inhibits the cell damage and develops the cell growth present in the skin.

\section{Evaluation of Antibacterial Activity}

The antibacterial activities of seaweed extract and treated fabric are tested on the standard of theDisc diffusion method and ENISO 20645 test methods.It was determined mainly by two bacterial species such as Staphylococcus aureus and Escherichia coli. The size of the sampleistaken in the range of $1.5 \times 10^{8} \mathrm{CFU} / \mathrm{ml}$. In both test methods, the result shows that the excellent antibacterial activity was attained againstStaphylococcus Aureus compared toEscherichia Coli.

\section{Disc diffusion method for extract}

The test result shows that a maximum of $28 \pm$ $1.5 \mathrm{~mm}$ of inhibition zone was occurred at $200 \mu \mathrm{g} / \mathrm{ml}$ forStaphylococcus Aureus compared to Escherichia Coli as shown in Table 3.5 and Fig. 3.4.The higher inhibition zone was attained due to the presence of bioactive compounds such as phenols, tannins, and saponins attributed to the excellentantibacterial activity of the seaweed extract[17].

Table 3.5 Disc diffusion method of extract

\begin{tabular}{|c|c|c|c|c|c|}
\hline S.No. & Seaweed & Extraction & $\begin{array}{c}\text { Concent } \\
- \text { ration } \\
(\boldsymbol{\mu g} / \mathbf{m l} \mathbf{)}\end{array}$ & $\begin{array}{c}\text { Staphylo } \\
\text { coccus } \\
\text { Aureus } \\
(\mathbf{m m})\end{array}$ & $\begin{array}{c}\text { Escheric } \\
\text { hia } \\
\text { Coli(mm) }\end{array}$ \\
\hline 1. & $\begin{array}{c}\text { Acanthophora } \\
\text { Spicifera }\end{array}$ & Methanol & 100 & $17 \pm 3.9$ & $13 \pm 1.3$ \\
\cline { 4 - 6 } & & 200 & $28 \pm 1.5$ & $23 \pm 2.6$ \\
\hline
\end{tabular}
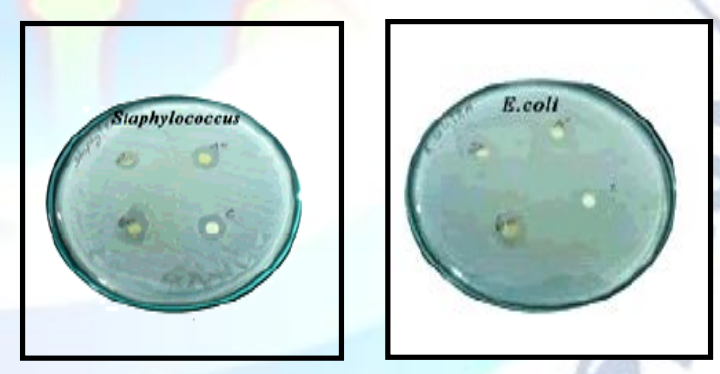

(a) Staphylococcus Aureus (b) Escherichia Coli

Fig 3.4: Antibacterial activity of Acanthophora Spicifera extract

\section{ENISO 20645 method for treated fabric}

The test result shows that the maximum of $28 \mathrm{~mm}$ of the inhibition zone was occurring againstStaphylococcus Aureus compared to Escherichia Coli as shown in Table 3.6 and Fig.3.5[18]. The treated fabric has a property to inhibit the growth of bacteria to a maximum extent was mainly due to the presence of bioactive compounds such as phenols, tannins, and saponinsattributed to theexcellent antibacterial property.

Table 3.6 Antibacterial activity of treated fabric 


\begin{tabular}{|r|c|c|c|c|}
\hline S. & \multirow{2}{*}{$\begin{array}{c}\text { Fabric } \\
\text { No. }\end{array}$} & Sample & Seaweed & \multicolumn{2}{|c|}{ Zone of Inhibition (mm) } \\
\cline { 4 - 5 } & Sample & $\begin{array}{c}\text { Staphylococcus } \\
\text { Aureus }\end{array}$ & $\begin{array}{c}\text { Escherichia } \\
\text { Coli }\end{array}$ \\
\hline 1. & $\begin{array}{c}100 \% \mathrm{Ba} \\
\text { mboo }\end{array}$ & $\begin{array}{c}\text { Acanthophora } \\
\text { Spicifera }\end{array}$ & 28 & 25 \\
\hline
\end{tabular}
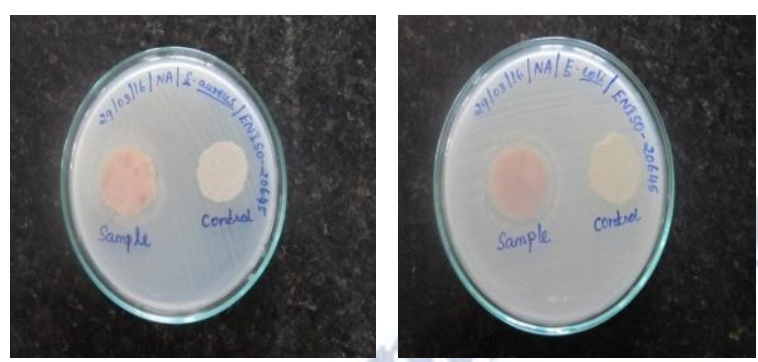

(a)Staphylococcus Aureus(b) EscherichiaColi

Fig 3.5: Antibacterial activity of Acanthophora Spicifera extract treated fabric

The above figure shows that the zone of inhibition was clearly seen on the sides of the treated fabric against Staphylococcus Aureusand Escherichia Coli.

\section{ENISO 20645 method of treated fabricafter washing}

The test result shows that after repeated washing cycle of 20 times the treated fabric had an excellent antibacterial activityis shown in Table 3.7.

Table 3.7Antibacterialactivity of treated fabric after washing

\begin{tabular}{|c|c|c|c|c|}
\hline \multirow{2}{*}{$\begin{array}{l}\text { S. } \\
\text { No. }\end{array}$} & \multirow{2}{*}{$\begin{array}{l}\text { Fabric } \\
\text { Sample }\end{array}$} & \multirow{2}{*}{$\begin{array}{c}\text { Seaweed } \\
\text { Sample }\end{array}$} & \multicolumn{2}{|c|}{ Zone of Inhibition (mm) } \\
\hline & & & $\begin{array}{l}\text { Staphylococ } \\
\text { cusAureus }\end{array}$ & $\begin{array}{c}\text { Escherichia } \\
\text { Coli }\end{array}$ \\
\hline 1. & $\begin{array}{c}100 \% \mathrm{Ba} \\
\mathrm{mboo}\end{array}$ & $\begin{array}{c}\text { Acanthophora } \\
\text { Spicifera }\end{array}$ & 26 & 23 \\
\hline
\end{tabular}

(a) Staphylococcus aureus(b)Escherichia coli

Fig 3.6:Antibacterial activity of Acanthophora Spicifera treated fabric after washing

The detergents used in washing will not affect the treated fabric, because the extract is evenly coated on the interstices of the fabrics and the affinity against detergents is lower and the better inhibition against pathogenic bacteria after repeated washing is shown in Fig.3.6[18].

\section{Analysis thetensile strengthof treated and untreated fabrics}

The tensile strength test of both treated and untreated fabrics is tested according to the ASTM D5034-95 standard. The results obtained from the tensile strength test arepresented inTable 3.8[22].

Table 3.8 Tensile strength of the treated and untreated fabric

\begin{tabular}{|c|c|c|}
\hline & Untreated Fabric & Treated Fabric \\
\cline { 2 - 3 } & Warp way sample & Weft way sample \\
\hline
\end{tabular}

\begin{tabular}{|c|c|c|c|c|}
\hline S.No. & \begin{tabular}{|c|}
$\begin{array}{c}\text { Strength } \\
(\mathrm{kg})\end{array}$ \\
\end{tabular} & $\begin{array}{c}\text { Elongation } \\
(\mathrm{mm})\end{array}$ & \begin{tabular}{|c}
$\begin{array}{c}\text { Strength } \\
(\mathrm{kg})\end{array}$ \\
\end{tabular} & $\begin{array}{c}\text { Elongation } \\
(\mathrm{mm})\end{array}$ \\
\hline 1. & 30.1 & 14.3 & 21.3 & 10.4 \\
\hline 2. & 32.4 & 15.4 & 19.6 & 10.0 \\
\hline 3. & 26.1 & 12.5 & 19.5 & 10.2 \\
\hline 4. & 31.5 & 14.6 & 23.1 & 10.7 \\
\hline 5. & 28.2 & 13.5 & 20.1 & 10.0 \\
\hline lean & 29.66 & 14.06 & 20.72 & 10.26 \\
\hline
\end{tabular}

The result shows that the tensile strength increases with a decrease in elongation in the untreated fabric compared to treated fabric. In the case of treated fabric, the tensile strength decreases with an increase in elongation of the fabric was mainly due to bio-scoured, bio-bleached, and finishing condition or evenly coated on the surface of the fabric.

Analysis the tearing strength of treated and untreated fabrics

The tearing strength test of both treated and untreated fabrics is tested according to the ASTM D1424-96 standard. The results obtained from the tearing strength test arepresented inTable 3.9[23].

Table 3.9 Tearing strength of the treated and untreated fabric

\begin{tabular}{|c|c|c|c|c|}
\hline \multirow{2}{*}{ S.No. } & \multicolumn{2}{|c|}{ Untreated Fabric } & \multicolumn{2}{c|}{ Treated Fabric } \\
\cline { 2 - 5 } & Warp (kgf) & Weft (kgf) & Warp (kgf) & Weft (kgf) \\
\hline 1. & 2.92 & 3.24 & 2.79 & 3.20 \\
\hline 2. & 2.86 & 3.03 & 2.76 & 2.89 \\
\hline 3. & 2.84 & 3.52 & 2.68 & 3.15 \\
\hline 4. & 2.85 & 3.59 & 2.83 & 3.53 \\
\hline 5. & 2.72 & 3.17 & 2.65 & 2.78 \\
\hline Mean & 2.83 & 3.31 & 2.74 & 3.11 \\
\hline
\end{tabular}
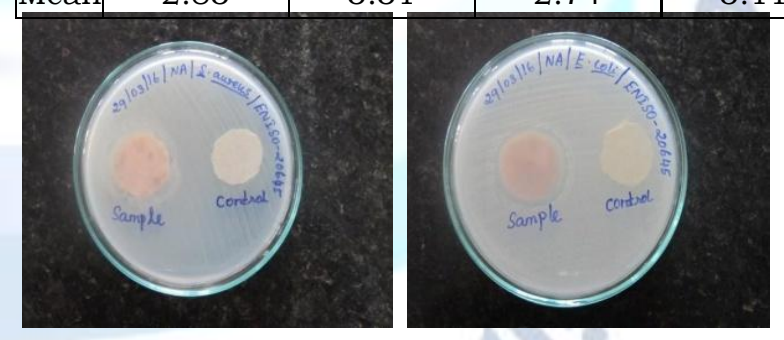

resultshows that the tearing strength increases for untreated fabric compared to treated fabric.In the case of treated fabric, the bio-scoured, bio-bleached, and finishing treatment deteriorates the tear strength of the fabric from both warp and weft side was mainly due to the carboxylic acidic grouppresent in the extracts that weakens the fibres. The acidic nature of the extracts hydrolyzes the cellulose present in the bamboo fabric more quickly will reduce the tearing strength of the treated fabric compared to untreated fabric. 


\section{Assessmentofair permeabilityproperties}

The permeability of air is asignificantfeature in the performance of treated and untreated fabrics were tested according to ASTM D737-96 standard.The results obtained from the fabric air permeability test are shown in Table 3.10[24].

Table 3.10 Air Permeability test

\begin{tabular}{|c|c|c|}
\hline S.No. & Untreated fabric & Treated fabric \\
\hline 1. & 50.9 & 49.3 \\
\hline 2. & 51.2 & 49.7 \\
\hline 3. & 52.7 & 50.5 \\
\hline 4. & 53.5 & 51.9 \\
\hline 5. & 53.4 & 52.8 \\
\hline Mean & 52.34 & 50.84 \\
\hline
\end{tabular}

The test result shows that the air permeability increases for the untreated fabric compared to treated fabric.In the case of treated fabric due to the absorption of the extract on the interstices between the yarns present in the fabric will decrease the fabric cover factor and pore size will reduce the air permeability. Whereas in untreated fabric, the fabric cover factor and pore size remain the same will increase the permeability of air passed through the fabric.

\section{Assessment of washing fastness oftreated fabric}

It is used to provide an indication of the removal of extract present on the surface of the fabric and it will affect the performance and aesthetic value of the fabric. The treated fabric washing with different cycles $(5,10,15$,and20) will have a very good wash fastness after repeated washing. At each stage of washing take place, the grade change for the white and colour fabric was in the range of 3-4 as shown in Table 3.11[25].

Table3.11Washing fastness test

\begin{tabular}{|c|c|c|c|}
\hline $\begin{array}{l}\text { Cycle of } \\
\text { Washing }\end{array}$ & $\begin{array}{l}\text { Fabric } \\
\text { Types }\end{array}$ & $\begin{array}{c}\text { Evaluate the } \\
\text { Colour } \\
\text { Change Grade }\end{array}$ & $\begin{array}{c}\text { Evaluate the } \\
\text { Staining } \\
\text { Grade }\end{array}$ \\
\hline 5 & \multirow{4}{*}{$\begin{array}{c}\text { Treated } \\
\text { fabric }\end{array}$} & 4 & 3 \\
\hline 10 & & 4 & 3 \\
\hline 15 & & 4 & 3 \\
\hline 20 & & 4 & 3 \\
\hline
\end{tabular}

The result clearly proved that even absorption of extract takes place in between the intermolecular structure of the yarn present in the treated fabric. The amount of extract absorbed in the fabric was not cleavage between the fibre present in the yarn. It also forms astrong bond between the fibre will lead to uniform uptake of the extract and minimum amount of the extract are removed at the surface of fabric during repeated washing after 20 cycles.

\section{Assessment ofrubbing fastness properties of treated fabric}

It is used to provide an indication of the removal of the extract on the surface of the fabric during rubbing on both dry and wet samples. The result obtained from the fabric rubbing fastness test is shown in Table 3.12[25].

\section{Table 3.12 Rubbing fastness test}

\begin{tabular}{|c|l|c|}
\hline S.No. & \multicolumn{1}{|c|}{ Particulars } & Rating \\
\hline 1. & $\begin{array}{l}\text { The numerical rating for change } \\
\text { in colour of the dry specimen }\end{array}$ & 5 \\
\hline 2. & $\begin{array}{l}\text { The numerical rating for change } \\
\text { in colour of the wet specimen }\end{array}$ & 4 \\
\hline 3. & $\begin{array}{l}\text { The numerical rating for change } \\
\text { in colour of the dry - wet } \\
\text { specimen }\end{array}$ & 4 \\
\hline 4. & $\begin{array}{l}\text { The numerical rating for change } \\
\text { in colour of the wet - dry } \\
\text { specimen }\end{array}$ & $4-5$ \\
\hline
\end{tabular}

The result shows that for the dry samples, the rubbing fastness properties are good compared to wet samples. In the wet state of the treated fabric, the extract applied on the surface is slightly removed after repeated rubbing as per the ASTM (08) standard and the grade result in the range of Good to Excellent.

In the dry state of treated fabric shows good fastness property, because of the strong fixation of seaweed extract on the intermolecular structure of the fabric, will increase the affinity between the extract and the fabric pore size.

\section{Assessment of wicking behavior oftreated and untreated fabrics}

It is used to find the water absorbency on the strip of the fabric against time in seconds. The results obtained from wickability test of the treated and untreated fabrics are shown in Table 3.13.

Table 3.13 Wickability test

\begin{tabular}{|c|c|c|c|}
\hline S.No. & $\begin{array}{c}\text { Time } \\
\text { (Sec) }\end{array}$ & $\begin{array}{c}\text { Untreatedf } \\
\text { abric }\end{array}$ & $\begin{array}{c}\text { Treated } \\
\text { fabric }\end{array}$ \\
\hline 1. & 5 & 3.6 & 2.9 \\
\hline 2. & 10 & 3.5 & 2.8 \\
\hline 3. & 15 & 3.5 & 2.8 \\
\hline 4. & 20 & 3.4 & 2.7 \\
\hline 5. & 25 & 3.4 & 2.6 \\
\hline
\end{tabular}

The result shows that the treated fabric is absorbed little less compared to untreated fabric because the seaweed extract are absorbed in the intermolecular structure between the yarns will increase the weight of the treated fabric[26].

\section{CONCLUSION}

In this study, Acanthophora Spicifera seaweed was collected from different sites that were screened for bioactive compounds, antioxidant, and 
antibacterial activity.The Acanthophora Spicifera seaweed extraction process wascarried out in a Soxhlet apparatus using methanol as a solvent for finishingbamboo fabric inhealthcare and hygienic applications. The bioactive compounds present in seaweed were confirmed by usingthe TLC technique and the functional group present in the seaweed extract was confirmed using FTIR spectroscopy analysis.Antioxidant properties of the red seaweed extract and the treated fabric was confirmed by using DPPH free radical scavenging activity. The results indicate that the presence of phenol, flavonoids, and anthocyanins compounds should be major contributors toexcellent antioxidant activity.

Antibacterial activity of the seaweed extract and the treated fabric was confirmed using disc diffusion and ENISO 20645 test methods. The results indicate that Acanthophora Spicifera extracts exhibit a promising antibacterial activity against Staphylococcus aureus and Escherichia Coli.The maximum zone of inhibition was around $28 \mathrm{~mm}$ was achieved in both extract and treated fabricscompared to untreated fabrics. The treated fabric has better durability after repeated washing and the antimicrobial property remains withstand after 20 washing cycles. The physical and comfort properties like tensile strength, tearing strength, air permeability, and wicking behaviour of the treated fabrics were decreases compared to untreated fabrics. The treated fabrics are used for a variety of medical applications such as gloves, surgical drapes, wound healing, operation room table covers, and face masks for hygienic and healthcare textiles.

\section{REFERENCES}

[1]"Medical Textiles: Application of Implantable Medical Textiles",Shah Md. Maruf Hasan, Md. Shahjalal, Jaglul Hoque Mridha, AM. Riasat Alam, GJMR2019.

[2]"Recent Advances in Antimicrobial Treatments of Textiles",Y. Gao, R. Cranston,TRJ2008.

[3]. "Nano herbal grafted medical textiles for production of antimicrobial textile,MH. Patel, PB. Desai,IJFTR 2014.

[4] "Development of medical textile market",R.Czajka,FTEE2005.

[5]"Medicinal and pharmaceutical uses of seaweed natural products: A review",Albertus J. Smit, JAP 2004.

[6] "Antibacterial activities of some marine algae from the Aegean Sea",E. Taskin,M. Ozturk, and O. Kurt,AJB2007.

[7]"Antimicrobial Activity of Extracts from Six Green Algae from Tanzania". MSP. Mtolera,AK. Semesi,CTMBREAR 1996.

[8] "Anticoagulant activity of marine green and brown algae collected from Jeju Island in Korea", A. Yasantha, L. Ki-Wan, K. Se-Kwon,J. You-Jin,BT2007.

[9] "Inhibition of herpes virus replication by marine algae extracts",EF. Deig, DW. Ehresmann,MT. Hatch,DJ.Riedlinger, AAC 1974.
[10] "A comprehensive study on different methods of extraction from guajava leaves for curing various health problem",Vibha Porwal, Pallavi singh, Devendra Gurjar, IJERA 2012.

[11] "Effects of scouring with enzymes, organic solvents, and caustic soda on the properties of hydrogen peroxide bleached cotton yarn",G. Buschle-Diller, Y. El Mogahzy, MK. Inglesby, SH. Zeronian,TRJ1998.

[12] "Enzymatic Bleaching of Cotton Fabric with Glucose Oxidase",Gisela Buschle-Diller, Xiang Dong Yang, and Ryohei Yamamot. TRJ2001.

[13] "Comparative study of cotton fabric finished with commercial andbio-active antibacterial agent by dip-dry and pad-dry methods", A. Reshm,K. Amutha,K. Kalaiarasi,V. Brindha Priyadarisini,EJBPS2018.

[14] "Analysis of herbal products by thin-layer chromatography: A review",Abdalkader Salih Mohammad, Bhawani, Sharma. IJPBS 2010.

[15]. "A study of microcapsules containing psidium guajava leaf extract for antibacterial agent on cotton fabric",Jiraphorn Katewaraphorn, Arunee Kongdee Aldred,IJCEA 2016.

[16] "Antioxidant Activity of Various Tea Extracts in Relation to their Antimutagenicity",GC.Yen, HY.Chen, JAFC1995.

[17] "Antibacterial Activity of Various Plants Extracts Against Antibiotic-resistant Aeromonas hydrophila", Shaza Anwar Al Laham, Frdoos Mohammad Al FadelJJM2014.

[18]"TheEvaluation of Antibacterial Activity of Fabrics Impregnated withDimethyltetradecyl(3-(Trimethoxysilyl) Propyl) Ammonium Chloride",A. Kimiran Erdem, NO. Sanli Yurudu, IUFSJB2008.

[19] "Phyto- chemical analysis of red alga Acanthophora Spicifera(Vahl) collected from Mumbai, India", SD. Shankhadarwar,JCPR2015.

[20] "Synthesis of Bioethanol by Dark Fermentation Using Marine Seaweed Acanthophora Spicifera(Vahl.) Borgesen as a Cheap Substrate",A. Umamaheswari,P. Saranraj,G. Rajesh Kanna,S. Elumalai,T. Sangeetha,BE2017.

[21] "Screening of phytochemical, antioxidant activity and anti-bacterial activity of marine seaweeds",T. Rajasekar,A. Mary shamya,M. Jerrine joseph, IJPPS 2019.

[22] "The Effects of Alkali Treatment on the Mechanical Properties of Jute Fabric Reinforced Epoxy Composites", Macaulay M. Owen,IJFTR 2014.

[23] "Optimisation of process conditions of cotton fabric treatment with Terminalia Chebula extract for antibacterial application",R. Rathinamoorthy, G. Thilagavathi, IJFTR2013.

[24]"Herbal Extract as an Ecofriendly Antimicrobial Finishing of Cotton Fabric", A. El-Shafei,S. Shaarawy,FH. Motawe,R. Refaei,EJC 2018.

[25] "Analysis of colour fastness of fabrics treated with dyes extracted from Roselle calyces",U. Ozougwu Stella,U. Anyakoha, AJAR 2017.

[26] "Study of Chemical Treated Cotton Fabric for Functional finishes using Chitosan",J. Jeyakodi Moses, VK. Venkataraman, JTATM2016. 